\title{
ENTREPRENEURIAL LEARNING ABOUT THE VENTURE CAPITALIST COMMUNITY
}

\author{
Dr. Ron Berger*1 \\ ${ }^{1}$ College of Law \& Business, 26 Ben Gurion St., Ramat Gan, Israel \& Sheffield Business School \\ City Campus, Sheffield S1 1WB, ronb@clb.ac.il
}

\begin{abstract}
Entrepreneurs are exceptional learners (Smilor, 1997) but are also exceptional at creating value. Do venture capitalists and institutional investors accurately value the efforts of the entrepreneur? We believe that venture capitalists and the investment community combine economics and market criteria with institutional and social criteria in making their investment decisions towards entrepreneurs. This paper provides a conceptual framework on how entrepreneurs need to "learn" the rules and norms of such institutional signals of venture capitalists and the investment community, in order to receive the appropriate compensation for their entrepreneurial business efforts.
\end{abstract}

\section{Keywords}

Entrepreneurs, venture capitalists, institutional investors, investment community

\section{JEL Classification}

E22, G24, L26

DOI: https://doi.org/10.14311/bit.2018.01.01

Editorial information: journal Business \& IT, ISSN 2570-7434, CreativeCommons license (c) (1) published by CTU in Prague, 2018, http://bit.fsv.cvut.cz/ 


\section{Introduction}

Entrepreneurs are exceptional learners (Smilor, 1997, 2001) and create great value for business and society. Learning in turn is social and collective and based on institutional norms (North, 1990) and rules. The field of business, institutions and society has become a crucial area of social science and management research. Three major models have dominated the research in the area of business and society. Models of corporate social performance (Steier, 2003; Carroll, 1979; Wood, 1991a, 1991b), focusing on the internal aspects of the firm; social control of business (Van de Ven and Engleman, 2003; Jones, 1995) focusing on the external environment of the firm; stakeholder models (Carlsson and Mudambi, 2003; Donaldson and Preston, 1995; Freeman, 1984; Hill and Jones, 1992), focusing on the various actors that constrain and influence the firm's behavior and performance.

These models help to address the on going academic debate between the neoclassical economic driven assumption about market competition, relatively perfect information, countless transactions and opportunism, and the more behavioral based foundations of cooperation and trust in business and society (Freeman, 1984; Dickson, 1992). But because of the diversity of stakeholder interests, stakeholder theories have difficulties in terms of measurement and performance in the market place. Entrepreneurs, given their need to learn from all stakeholders including customers, suppliers, competitors, employees (Smilor, 1997, 2001) need to integrate the needs of both business and society. A key question is, do venture capitalists and institutional investors accurately measure and value the efforts and roles of entrepreneurs in society?

Research such as Van de Ven and Engleman (2003), Donaldson and Preston (1995), have integrated the three major aspects of descriptive accuracy, instrumental power and normative validity of stakeholder theories. Their works and other earlier works such as Freeman (1984) have helped to raise fundamental issues which combine the purely economics and competition driven aspects of firms, along with the more social, cooperative aspects of exchange. These works overlap with the research of Granovetter (1985), Coleman (1990) and Burt (1992) which helped to show the importance of embeddedness in the social structure, and the role of social capital. Both strands of research however, assume that the value of the products and services provided by the firm in the market place is measurable, tangible, lacking ambiguity. Thus, uncertainty for stakeholders has to do more with agency and monitoring problems (Jensen and Meckling, 1976; Eisenhardt, 1989) rather than the nature of intangibility of the firm's quality and the implications for exchange.

The high technology bubble of the late 1990's and its subsequent burst in the early 21st century helped to illuminate the mismatch and information asymmetry that can occur between entrepreneurs and venture capitalists and the investment community (Shiller, 2000). In this article, we try and integrate stakeholder theories in the context of entrepreneurs, and institutional investors such as venture capitalists; and the learning interaction between the two parties. Investors combine not only economic and market criteria, but also social and institutional criteria in their valuation of entrepreneurs and new business ideas. Although market signals have been well researched (Spence, 1974), we believe that entrepreneurs, because they are exceptional learners (Smilor, 1997, 2001) require a broader concept of, institutional signals. The valuation of entrepreneurs and their efforts will depend on institutional factors; thus such "institutional learning", learning about the community of venture capitalists and the investment community, is also a key criterion for entrepreneurs and their potential success rates. The purpose of this conceptual note is to provide a preliminary conceptual framework of this idea, and to contribute to the literature on entrepreneurship and learning. 


\section{Quality of Entrepreneurial Ventures and Stakeholders}

As analysed in recent works such as Reeves et al. (1994); Dean and Bowen (1994); Bitner (1990); Bolton and Drew (1991); Spencer (1994); Waldman (1994), the research defining quality and its linkage to outcomes such as market share, costs, profits in manufacturing industries has led to conflicting results. The concept of quality, which has been reviewed in Reeves and Bednar (1994) has been defined in many ways, including conformance to specifications (Levitt, 1972); fitness for use (Juran, 1988); meeting customers' expectations (Parasuraman, Zeithaml, and Berry, 1985). The issue of quality intangibility and even the definition of quality itself (Reeves and Bednar, 1994; Zeithaml, Parasuraman and Berry, 1990; Curry, 1985; Brown, Chruchill and Peter, 1993) has become increasingly complex, as many of the world's major industries have shifted to services and knowledge based industries. Can the quality of an entrepreneur's new venture be easily measured?

What is fundamental to our analysis is the role of measurement costs (Barzel, 1982; North, 1990). The concept of stakeholder theory raises measurement problems, because of the diversity of stakeholder interests; this is especially true in service and knowledge based industries, because of the inherent intangibility of product and service quality in these industries (Spender and Grant, 1996; Hosmer, 1995). We believe that when such measurement problems exist, firms and clients tend to further depend on market signals and external cues and the evaluation made by other organizations in the market, which serve as external cues of certification and measurement. This becomes an issue for even the more narrow, economic based definitions of market competition and success. But the difficulties of defining quality and its linkages to success such as profits, is especially difficult under stakeholder theories, since performance needs to be more broadly, and often socially defined (Jones, 1995; Donaldson and Preston, 1995). We provide a preliminary framework for analysing how such external cues and certification can define a firm's quality in the market to its stakeholders.

An ideal way of classifying products for our current purposes is found in the work of Nelson (1970) who, building on Stigler's earlier work, developed a typology which distinguishes between search and experience goods. The quality of search goods can be ascertained before purchase, common examples being transport services or cheap clothing. The quality of experience goods, however, can be learnt only after use, good examples being holidays and restaurants meals. Darby and Karni (1973) developed this typology by identifying a third category, for which they coined the term credence goods; Nayaar (1990) and Nayyar and Kazanjian (1993) have also analyzed the importance of such information asymmetries, and economies of scope, but from the angle of firm diversification. Credence goods are goods whose quality is rarely learned, even after purchase and use. Examples of such credence goods are numerous and include the worth of a transfer of title on a property, the impact of the services of a particular graphic artist or copywriter in an advertising campaign or the quality of care received on hospitalisation for a non-specific medical problem. In our opinion, the quality and value of an entrepreneur's new business is similar to a credence (Darby and Karni, 1973) good.

The research on stakeholder theory also needs to incorporate the difficulties that firms may face in reaching social measures of performance (Swanson, 1995; Jones, 1995), which may also be affected by the intangibility of quality in many service and knowledge driven industries. Our key research question then is what additional factors help to determine an entrepreneur's firm's quality, position in the market when quality certainty is no longer guaranteed. In this sense, if market signals (Schelling, 1960; Spence, 1973; Heil and Robertson, 1991) help to overcome uncertainty in general, an important issue is which signals influence the venture capitalists and the investment community? 


\section{Signals, Invisible Assets}

The diversity of stakeholder interests (Jones, 1995; Donaldson and Preston, 1995; Freeman, 1984; Hill and Jones, 1992) creates difficulties in measurement and in determining a firm's performance. With the existence of measurement costs (Barzel, 1982; North, 1990), external intermediaries can also play a potential role in certifying the content and value of an firm's products or services. Under such uncertainty, the evaluation of a firm's products and services is also influenced by external organizations, which help to certify and measure the quality and content of a firm's products or services. This idea overlaps with recent works such as Podolny (1993); Camic (1992); Haunschild (1994); Carter and Manaster (1990), which have recently further developed the earlier works of White (1970); Sorensen (1983); Bonacich (1987); Simmel (1950); Dutton and Jackson (1987), to show that a firm's position in the social structure can in turn affect not only rewards, but can reduce the firm's ability to interact with firms with different social status. We believe that this basic idea of interdependence can be taken further.

For a new entrepreneur's new venture, where the quality and content of the product or service being exchanged is uncertain, external cues like intermediaries help to measure and certify a firm and its quality in the market place for its stakeholders. Such external cues help to identify a firm's, "invisible" assets. Itami and Roehl (1987) have also noted that traditional research has tended to define assets too narrowly, focusing on the tangible assets, such as plant and equipment. They note that invisible assets such as accumulated consumer information, brand name reputation, management skill, corporate cultures are just as important to the success of the firm. But the existence or possession of such invisible assets can be more easily communicated to the other party, if the backgrounds of the two parties are shared. Such shared backgrounds allow each party to find the points of salience, or focal points (Schelling, 1960), creating a more bilateral relationship as in relationship marketing, rather than an anonymous, multilateral market exchange.

Proposition 1: It is easier to send and receive a clear signal when the backgrounds of the two parties are shared; focal points for exchange can be more effectively found.

We believe that information concerning such invisible assets can be revealed in a slightly different way than for tangible assets, to competitors and the market. If the invisible assets are rare, and imperfectly imitable, then this will provide the firm with a sustained advantage over competitors. In turn, the ability to reveal such information and possession of invisible assets provides the firm with a competitive advantage that cannot be easily imitated. The importance of providing information indirectly to the market through market signals has been analyzed in great detail in Spence (1973); Robertson, Eliashberg and Rymon (1995); Choi and Hilton (1995); Heil and Langvardt (1994); Heil and Robertson (1991); Moore (1992); Gruca and Sudharshan (1995).

Proposition 2: The importance of shared background in sending and receiving signals leads to a separation of insiders and outsiders in such signal based communication, for example between entrepreneurs and the venture capital community

Milgrom and Roberts provide a more general definition of signals:

"...signals demonstrate to others the actor's intentions or abilities or some other characteristic about which the actor has private, unverifiable information."

(Milgrom \& Roberts, 1992) 
An example of a signal would be a firm's willingness to provide a money back guarantee for its product, to signal to consumers the firm's commitment and confidence in the product. One of the problems with signals is that they can be, manipulated by the firm, in order to provide what could be deceptive information about its invisible assets. For example, there is no guarantee that a firm's willingness to provide money back guarantees will actually ensure good value and a high quality product for the consumer. A distinction now needs to be made between signals and, indices. A positive signal for one stakeholder, such as consumers may send the wrong signals to another stakeholder, such as alliance partners. Our key issue is whether certain signals can send an undeniably effective message to all stakeholders.

"Indices", as defined by Jervis (1985) are:

"....statements or actions that carry some inherent evidence that the image projected is correct because they are believed to be inextricably linked to the actor's capabilities or intentions."

Indices, unlike signals, cannot be as easily manipulated and are always true. Examples include private messages the perceiver overhears or intercepts. In some sense, an indice is a type of signal that cannot be manipulated, and is truthful in its information content. Our point is that if we make a distinction between signals and indices, such factors as a firm's history, or past success may play a role in the information conveyed by a firm. Kreps and Spence (1984) have in their work already noted the importance of history in the role of competition within industries. The ability to use indices, also depends on a particular, or rare experience, in that there is a linkage to some aspects of past success of the firm, an experience, which other competitors cannot easily imitate. As discussed by Stinchcombe (1965), Barney (1986), and Zucker (1977), the various symbols, beliefs and values that are part of a firm's culture will reflect the unique early history of the firm. Part of a firm's history of course can be success in the industry, such as leading to the establishment of a satisfied client base.

We believe that because indices are always truthful signals, only certain types of firms would have an incentive to use indices. Indices are more credible than signals, on the other hand, because not all firms want to convey information about their history, especially if it included various failures.

Proposition 3: Indices may be more widely used by successful firms, because indices are more credible than signals, and firms would like to convey their past successes with as much credibility as possible.

As mentioned before, providing a firm's year when it was established, implying the age, or information about the number of branches and stores, implying the size of the client base are indices, rather than signals. But because they are indices, they provide much more certain information to customers than signals, or claims about the quality of a entrepreneur's firm's product, quality, because such signals can be more easily manipulated. In a world where consumers often experience a proliferation of firms' signals and where it is difficult to distinguish between truths and bluffs, indices provide a highly credible way for an entrepreneur's firm to convey information. Organisations have different past histories. Indices, unlike signals, may allow organisations who have been successful in the past, or in other areas, to convey information credibly to customers. In turn, a firm with such positive invisible assets, or indices has an incentive to make it known to the market or to the industry. Such indices can be seen as more truthful by the stakeholders in the market, especially venture capitalists and the investment community. 
Proposition 4: Firms with indices that can be revealed as invisible assets, such as history, or the client base, have an incentive to provide this information to the market and consumers; firms that do not provide such information, in turn, may not possess such indices, or invisible assets.

Perceptions of customers are greatly influenced by factors that can prove firm success, present robustness of the firm's resources. In this sense, indices are especially important as invisible assets, because they can provide truthful information, knowledge about a firm's capabilities, and past successes. At the same time, such indices, as firm history, age, and its client base are difficult to imitate for competitors. In this sense, indices are an invisible, and non-imitable asset. The above four propositions, differentiating between signals in an identified type of exchange relative to an anonymous market exchange are integrated in Figure 1.

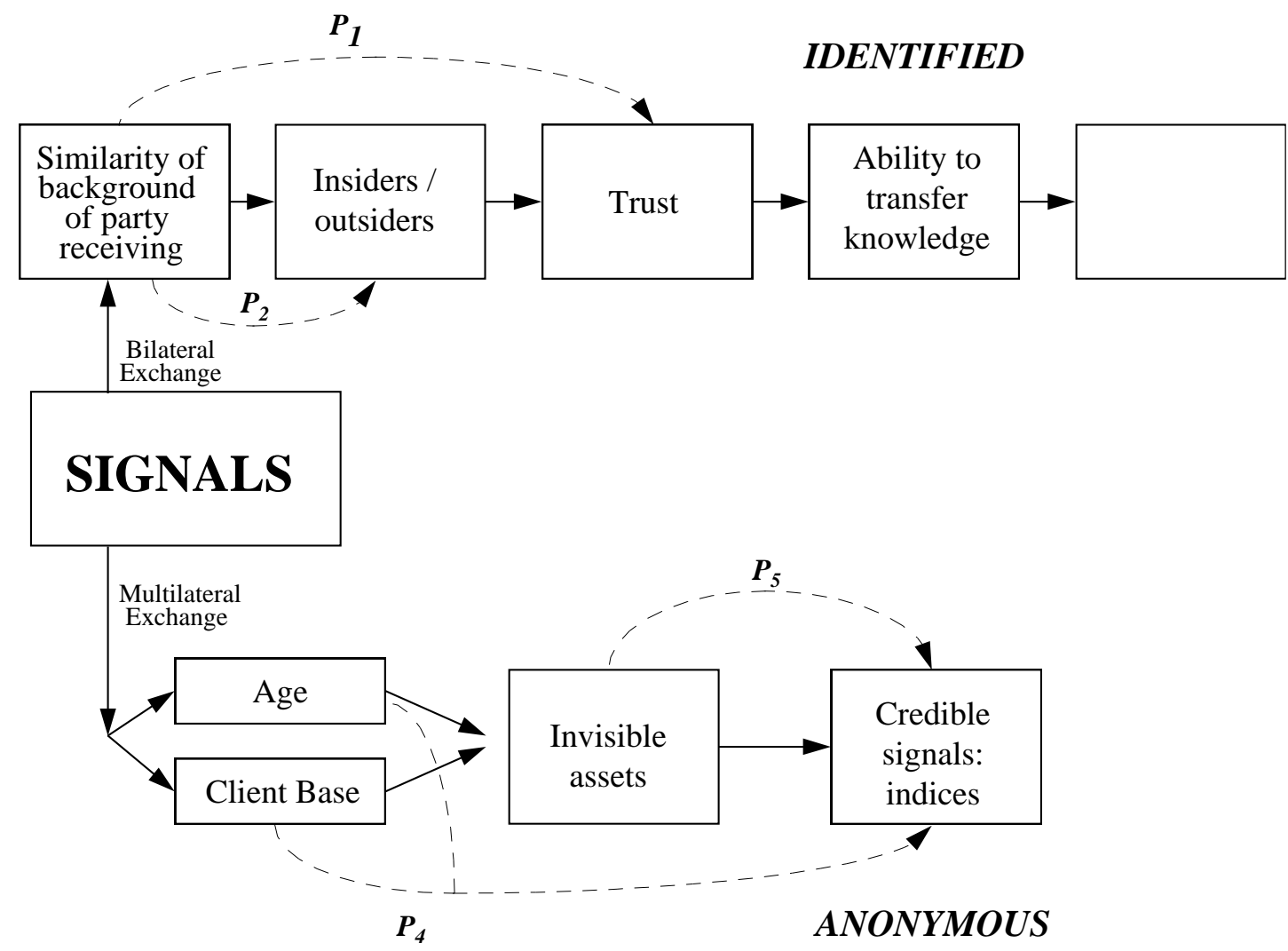

Figure 1. Signals, Invisible Assets and Indices.

\section{Stakeholders, Signals, Indices}

It is well known that external stakeholders play an important role in the success of companies. Doyle (1992) has shown how difficult it is for excellent companies to maintain their success over even several years; part of the difficulty of maintaining success is the need to respond to internal as well as external stakeholders. External commentary such as favorable commentaries in business publications create awareness, which can be used by companies in their marketing strategy (Rabino and Moore, 1989; Robertson, Eliashberg and Rymon, 1995). Although the increasingly turbulent and uncertain environment has increased the importance of such external factors, the existing literature has not conceptually framed how such factors can be analyzed. We believe that the earlier distinction between signals and indices help to clarify their roles. We believe there are four major indices (Jervis, 1985) or external measurement drivers, of relevance to stakeholders, for firms in industries where 
quality is intangible. Firstly, a firm's client base is a driver of quality; the position or status (Podolny, 1993; Frank and Cook, 1995) of the particular clients, can in turn help to elevate a firm's ranking and quality. Secondly, the ability and reputation for being innovative, such as developing new products, a dynamic corporate culture, are another type of index in the market place (Haunschild, 1994), affecting quality. Thirdly, a firm's networks, whether they be with collaborators, or with competitors can also be an index of quality in the market place. An example of this would be top ranked business schools (D'Aveni, 1996), being competitors but holding executive programmes or other conferences together in a network. Fourthly, outside external sources of information, such as Standard and Poor indices in financial markets; consumer reports written by private organizations; business magazines and commentaries all help to serve as an index of quality.

Proposition 5: A firm's value to stakeholders in industries where quality is intangible, is also affected by the following four indices: list of clients; reputation for successful innovation; network of partners or competitors; evaluation by external intermediaries.

The four indices, or truthful signals certify the firm's quality and status, providing an, "indirect" measurement to stakeholders.

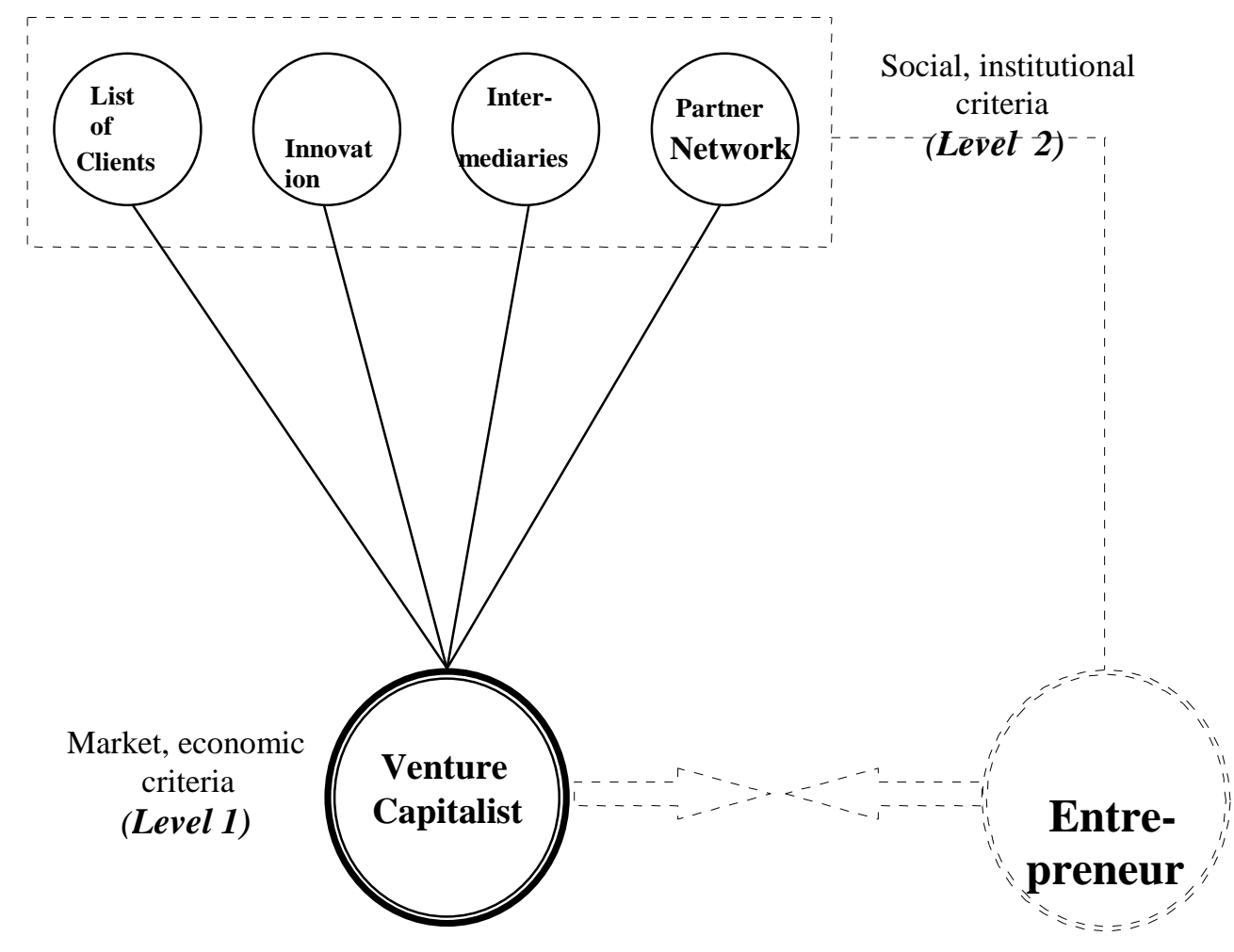

Figure 2. Venture Capitalists and Entrepreneurs - Institutional Criteria.

As we discussed earlier in this article, the definition of quality has varied, among conformance to specifications (Levitt, 1972); fitness for use (Juran, 1988); meeting customers' expectations (Parasuraman et al., 1985; Parasuraman, Berry and Zeithaml, 1993). Our existing analysis is that when there is quality intangibility, the various existing definitions of quality may still apply, but whether they meet the criteria of quality and success is also affected by these four external indices of measurement. A firm's overall and continued success in its market, or in its industry, needs to take into account these external factors; stakeholder theories, which measure the performance of firms 
and their responsiveness to external constituencies such as customers, government, society (Jones, 1995) also need to incorporate the role played by these external indices.

Our framework also helps further illustrate the behavioral research of Burt (1992), Feld (1981) and Granovetter (1985), on the importance of relationships within the social structure and how it influences competition. Stakeholders of the firm need to evaluate not only the competitiveness of the firm in the market, but also the firm's position in the social structure, and its relations with the four external indices of quality measurement; the abstract economics based model of anonymous exchange and competition is only a beginning. Research in stakeholder theories helps to bring together these two major frameworks in management research. The intangibility of quality in services and knowledge based industries, illustrates the importance of external cues, or indices in further identifying firms and determining their quality for stakeholders.

\section{Conclusion and discussion}

The purpose of this article was to analyse the entrepreneurial learning towards the venture capitalist and investment community. Entrepreneurs are known as exceptional learners - but whether they are exceptional learners towards the investment community is questionable. We analyzed the relationship among the entrepreneur's firm, stakeholders and external measurement through the concept of market signals (Schelling, 1960; Spence, 1973; Heil and Robertson, 1991). These external indices for such credence goods industries (Darby and Karni, 1973) include: list of clients; reputation for successful innovation; networks of partners or competitors; evaluation by external intermediaries. Entrepreneurs compete in the market against other entrepreneurs; however, they also maintain long term relations with these indices, or external drivers of measurement that help to overcome quality intangibility. We provided a preliminary framework for integrating such entrepreneurial learning about the venture capitalist and investment community.

Further research is warranted on the following issues. Firstly, there is a need to analyse in more depth the way quality and value can be measured for an entrepreneur's firm credence goods industries. The shift of many of the world's mature economies towards increased entrepreneurship, will make such research issues increasingly important. Secondly, there is a need to further research the dynamics of the relationship between market and social structure when stakeholders drive the success of entrepreneurial firms. The potential importance of stakeholder concepts require further research on integrating the role of signals, the measurement of entrepreneurial firms, and how to improve the accuracy of valuations towards entrepreneurial firms.

\section{References}

[1] Achrol, Ravi (1991), "Evolution of the Marketing Organisation: New Forms for Turbulent Environments," Journal of Marketing, 55 (January), 77-93.

[2] Anderson, J., M. Rungtusanatham and R. Schroeder (1994), "A Theory of Quality Management underlying the Deming Management Method," Academy of Management Review, 19, 472-509.

[3] Anderson, J. and J. Narus (1990), “A Model of Distributor Firm and Manufacturer Firm Working Partnerships," Journal of Marketing, 54 (January), 42-58.

[4] Arndt, J. (1979), "Toward a Concept of Domesticated Markets," Journal of Marketing, 43 (Fall), 69-75.

[5] Bitner, M. (1990), "Evaluating Service Encounters: the Effects of Physical Surroundings and Employee Responses," Journal of Marketing, 54, 69-82.

[6] Blau, P. (1975), Approaches to the Study of Social Structure. New York: Free Press.

[7] Bonacich, P. (1987), "Power and Centrality: a Family of Measures," American Journal of Sociology, 92, 1170-1183.

[8] Bolton, R. and J. Drew (1991), "A Longitudinal Analysis of the Impact of Service Changes on Customer Attitudes," Journal of Marketing, 55, 1-9. 
[9] Brown, T., G. Churchill and J. Peter (1993), "Improving the Measurement of Service Quality," Journal of Retailing, 69, 127-139.

[10] Bucklin, L. and S. Sengupta (1993), “Organizing Successful Co-Marketing Alliances,” Journal of Marketing, 57 (April), 32-46.

[11] Burt, R. (1992), Structural Holes. Cambridge: Harvard University Press.

[12] Camic, C. (1992), "Reputation and Predecessor Selection: Parsons and the Institutionalists," American Sociological Review, 57, 421-445.

[13] Carroll, A.B. (1979), "A Three Dimensional Conceptual Model of Corporate Performance, " Academy of Management Review, 4, 497-505.

[14] Carter, R. and S. Manaster (1990), “Initial Public Offerings and Underwriter Reputation,” Journal of Finance, 45, 1045-1068.

[15] Cohen, D. (1991), “Trademark Strategy Revisited,” Journal of Marketing, 55 (3), 46-59.

[16] Coleman, J. (1990), Foundations of Social Theory. Cambridge: Belknap Press of Harvard University Press.

[17] Cronin, J. and S. Taylor. (1992), “Measuring Service Quality: a Reexamination and Extension,” Journal of Marketing, 56, 55-68.

[18] Curry, D. (1985), “Measuring Price and Quality Competition,” Journal of Marketing, 49, 106-117.

[19] D’Aveni, R. (1996), "A Multiple-Constituency, Status-Based Approach to Interorganizational Mobility of Faculty and Input-Output Competition among Top Business Schools," Organization Science, 7, 166-189.

[20] Dant, R. and P. Schul (1992), "Conflict Resolution Processes in Contractual Channels of Distribution," Journal of Marketing, 56 (January), 38-54.

[21] Darby, M. and E. Karni (1973), "Free Competition and the Optimal Amount of Fraud," Journal of Law and Economics, 16, 67-88.

[22] Day, G. and R. Wensley (1988), “Assessing Advantage: a Framework for Diagnosing Competitive Superiority," Journal of Marketing, 52 (April), 1-20.

[23] Day, George (1994), "The Capabilities of Market-driven Organisation," Journal of Marketing, 58 (October), 37-52.

[24] Dean, J. and D. Bowen. (1994), “Management Theory and Total Quality: Improving Research and Practice through Theory Development," Academy of Management Review,19, 392-418.

[25] Dickson, P. (1992), "Toward a General Theory of Competitive Rationality," Journal of Marketing, 56, 6983.

[26] Donaldson, T. and L. Preston (1995), "The Stakeholder Theory of the Corporation: Concepts, Evidence and Implications," Academy of Management Review, 20, 65-91.

[27] Dutton, J.E. and Jackson, S. (1987), "Categorizing Strategic Issues: Links to Organizational Action," Academy of Management Review, 12, 76-90.

[28] Dwyer, R., P. Schurr, S. Oh (1987), “Developing Buyer-Seller Relationships,” Journal of Marketing, 51 (April), 11-27.

[29] Dwyer, R. and O. Walker (1981), “Bargaining in an Asymmetrical Power Structure,” Journal of Marketing, 45 (Winter), 104-115

[30] Eisenhardt, K. (1989), "Agency Theory: an Assessment and Review," Academy of Management Review, 14, 57-74.

[31] Feld, S. (1981), "The Focused Organization of Social Ties," American Journal of Sociology, 86, 10151034.

[32] Frank, R. and P. Cook (1995), The Winner-Take-All Society. New York: Free Press.

[33] Frazier, G., J. Gill and S. Kale (1989), "Dealer Dependence Levels and Reciprocal Actions in a Channel of Distribution in a Developing Country," Journal of Marketing, 53 (January), 50-69.

[34] Freeman, R. (1984), Strategic Management: a Stakeholder Approach. Boston: Pitman Press.

[35] Ganesan, S. (1994), "Determinants of Long-Term Orientation in Buyer-Seller Relationships," Journal of Marketing, $58(2)$, 1-19.

[36] Glazer, R. (1991), "Marketing in an Information Intensive Environment: Strategic Implications of Knowledge as an Asset," Journal of Marketing, 55, 1-20.

[37] Granovetter, M. (1985), "Economic Action and Social Structure: the Problem of Embeddedness," American Journal of Sociology, 91, 481-510. 
[38] Gundlach, G. and P. Murphy (1993), "Ethical and Legal Foundations of Relational Marketing Exchanges," Journal of Marketing, 57 (October), 35-46.

[39] Haunschild, P. (1994), "How much is that Company worth? Interorganizational Relationships, Uncertainty and Acquisition Premiums," Administrative Science Quarterly, 39, 391-411.

[40] Heil, O. and T. Robertson (1991), "Toward a Theory of Competitve Market Siganling: a Research Agenda," Strategic Management Journal, 12, 403-418.

[41] Hill, C. and T. Jones. (1992), "Stakeholder-Agency Theory," Journal of Management Studies, 29, 131154.

[42] Hirsch, P. and M. Lounsbury (1996), "Rediscovering Volition: the Institutional Economics of Douglass C. North," Academy of Management Review, book review essay, 21, 872-884.

[43] Hosmer, L. (1995), "Trust: the Connecting link between Organizational Theory and Philosophical Ethics," Academy of Management Review, 20, 379-403.

[44] Itami, H. with T. Roehl (1987), Mobilizing Invisible Assets. Cambridge, MA.: Harvard University Press.

[45] Jacobson, R. (1992), "The Austrian School of Strategy," Academy of Management Review, 17, $782-807$.

[46] Jensen, M. and W. Meckling (1976), "Theory of the Firm: Managerial Behavior, Agency Costs, and Ownership Structure," Journal of Financial Economics, 3, 305-360.

[47] Jervis, R. (1985), The Logic of Images in International Relations. Princeton: Princeton University Press.

[48] Jones, T. (1995), "Instrumental Stakeholder Theory: a Synthesis of Ethics and Economics," Academy of Management Review, 20, 404-437.

[49] Judd, R.C. (1964), “The Case for Redesigning Services," Journal of Marketing, 28, 58-59.

[50] Juran, P. (1988), A History of the Jews. New York: Harper and Row.

[51] Kreps, D. \& Spence, M. (1984), "Modeling the Role of History in Industrial

[52] Organization," In G. Feiwel (Ed.), Contemporary Issues in Modern Microeconomics. London: Macmillan.

[53] Levitt, T. (1972), “Production-line Approach to Service," Harvard Business Review, 50, 41-52.

[54] Lippman, S. \& Rumelt, R. (1982), “Uncertain Imitability: an Analysis of Interfirm Differences in Efficiency under Competition," Bell Journal of Economics, 13, 418-438.

[55] Milgrom, P. \& Roberts, J. (1992), Economics, Organization and Management. New Jersey: Prentice-Hall International.

[56] Mills, P. and N. Margulies (1980), "Toward a Core Typology of Service Organizations," Academy of Management Review, 5, 255-265.

[57] Moore, M. (1992), "Signals and Choices in a Competitive Interaction: the Role of Moves and Messages," Management Science, 4 (April), 483-500.

[58] Nayyar, P. (1990), "Information Asymmetries: A Source of Competitive Advantage for Diversified Service Firms," Strategic Management Journal, 11, 513-519.

[59] Nayyar, P. \& Kazanjian, R. (1993), “Organizing to Attain Potential Benefits from Information Asymmetries and Economies of Scope in Related Diversified Firms," Academy of Management Review, 18, 735-759.

[60] North, D. (1990), Institutions, Institutional Change and Economic Performance. Cambridge: Cambridge University Press.

[61] Parasuraman, A., L. Berry and V. Zeithaml (1993), “More on Improving Service Quality Measurement," Journal of Retailing, 69, 140-147.

[62] Parasuraman, A., V. Zeithaml, and L. Berry (1985), "A Conceptual Model of Service Quality and its Implications for Future Research," Journal of Marketing, 4, 41-50.

[63] Podolny, J. (1993), “A Status-Based Model of Market Competition,” American Journal of Sociology, 98, 829-872.

[64] Preston, L. and H. Sapienza (1990), "Stakeholder Management and Corporate Performance," Journal of Behavioral Economics, 19, 361-375.

[65] Reeves, C. and D. Bednar (1994), "Defining Quality: Alternatives and Implications," Academy of Management Review, 19, 419-445.

[66] Shostack, G. (1977), “Breaking Free from Product Marketing," Journal of Marketing, 41, 73-80.

[67] Simmel, G. (1950), "Superordination and Subordination," in K. Wolf translation, The Sociology of Georg Simmel. Illinois: Free Press. 
[68] Sinkula, James (1994), "Market Information Processing and Organisational Learning," Journal of Marketing, 58 (January), 35-45.

[69] Sorensen, A. (1983) "Processes of Allocation to Open and Closed Positions in Social Structure. Zeitschrift fuer Soziologie, 12: 203-224.

[70] Spence, M. (1973), Market Signalling. Cambridge: Harvard University Press.

[71] Spencer, B. (1994), “Models of Organization and Total Quality Management," Academy of Management Review, 19, 446-471.

[72] Spender, J.C. and R. Grant (1996), “Knowledge and the Firm: Overview," Strategic Management Journal, winter special issue, 17, 5-9.

[73] Stern, L. and T. Reve (1980), “Distribution Channels as Political Economies: a Framework for Comparative Analysis," Journal of Marketing, 44 (Summer), 52-64.

[74] Swanson, D. (1995), "Addressing a Theoretical Problem by Reorienting the Corporate Social Performance Model," Academy of Management Review, 20, 43-64.

[75] Teece, D.J., Pisano, G., \& Shuen, A. (1990), "Firm Capabilities, Resources, and the Concept of Strategy," working Paper, University of California at Berkeley.

[76] Waldman, D. (1994), "The Contributions of Total Quality Management to a Theory of Work Performance," Academy of Management Review, 19: 510-536.

[77] White, H. (1970), Chains of Opportunity: system models of mobility in organizations. Cambridge: Harvard University Press.

[78] Williamson, O.E. (1985), The Economics Institutions of Capitalism. New York: Free Press.

[79] Wood, D.J. (1991a), "Corporate Social Performance Revisited," Academy of Management Review, 16, 691-718.

[80] Wood, D.J. (1991b), "Social Issues in Management: Theory and Research in Corporate Social Performance," Journal of Management, 17, 383-406.

[81] Zeithaml, V. A. Parasuraman, L. Berry (1990), Delivering quality service. New York: Free Press. 